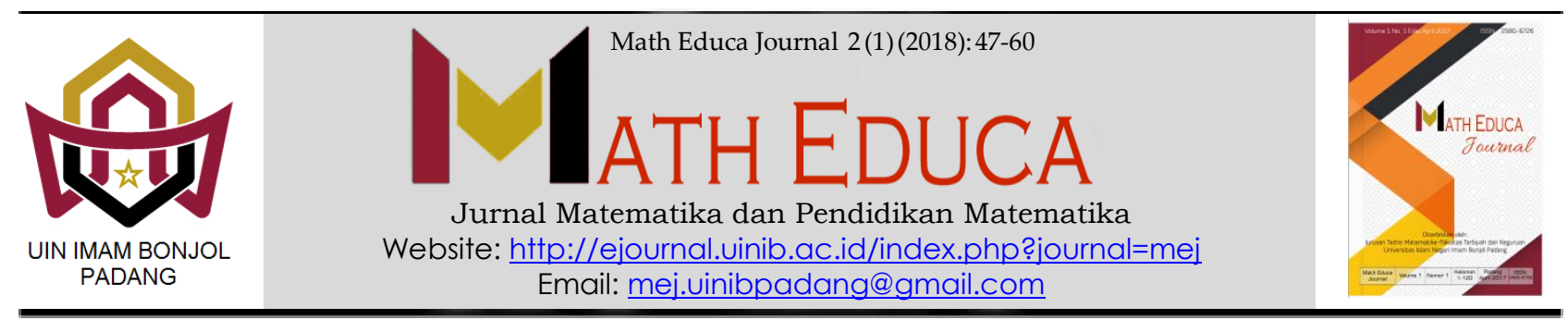

\title{
PENERAPAN MODEL PEMBELAJARAN KOOPERATIF TIPE LOTTERY CARD (KARTU ARISAN) UNTUK MENINGKATKAN KEMAMPUAN PEMAHAMAN KONSEP MATEMATIS SISWA KELAS X MAN SALIDO
}

\author{
${ }^{1}$ Rivdya Eliza, ${ }^{2}$ Riza Setia Eka Putri \\ ${ }^{1,2}$ Tadris Matematika, Fakultas Tarbiyah dan Keguruan, Universitas Islam Negeri Imam Bonjol Padang \\ Email: ${ }^{1}$ rivdyaeliza@gmail.com, riri_lagi@yahoo.com, ${ }^{2}$ setiariza@ymail.com
}

Received: January 2018; Accepted: March 2018; Published: April 2018

\begin{abstract}
Abstrak
Tujuan dari penelitian ini adalah untuk mengetahui kemampuan pemahaman konsep siswa yang diajar dengan model pembelajaran Kooperatif Tipe Lottery Card (Kartu Arisan) di kelas X MAN Salido. Jenis penelitian ini adalah penelitian eksperimen-semu dengan rancangan penelitian yang digunakan adalah Randomized Control Group Only Design. Dalam rancangan ini diambil sekelompok subjek dari populasi kelas XMAN Salido Tahun Pelajaran 2016/2017, sehingga nantiknya terpilih kelas eksperimen dan kelas kontrol. Untuk mendapatkan kelas sampel maka terlebih dahulu dilakukan uji normalitas, homogenitas dan kesamaan rata-rata untuk semua kelas populasi. Setelah semua kelas diketahui normal, homogen dan memiliki kesamaan rata-rata maka dilakukan pemilihan kelas sampel secara acak. Sebelum dilakukan pengujian hipotesis,dilakukan sebelumnya uji normalitas dan homogenitas pada sampel. Kemudian dilakukan pengujian hipotesis yang menunjukkan $t_{\text {hitung }}>t_{\text {tabel }}(1,838>1,645)$ dengan $\alpha=0,05$ pada selang kepercayaan $95 \%$, maka keputusannya adalah $H_{0}$ ditolak dan $H_{1}$ diterima artinya kemampuan pemahaman konsep matematika diajar dengan Model Pembelajaran Kooperatif Tipe Lottery Card (Kartu Arisan) lebih tinggi daripada kemampuan pemahaman konsep siswa diajar dengan pembelajaran konvensional.
\end{abstract}

Kata kunci : Kemampuan Pemahaman Konsep, Model Pembelajaran Kooperatif Tipe Lottery Card (Kartu Arisan)

\section{Abstract}

The Aim of this research were to figure out the learning concept comprehension of students at class $X$ at MAN Salidoin the academic year of 2016/2017 through Cooperative Studying Model Lottery Card Type (Arisan's Card). This was a quasi experimental research with Randomized Control Group OnlyDesign.The population of this research was of students at class X at MAN Salidoin the academic year of 2016/2017. Then, found that students as the experimental class and the control class. To get the class sample test done first then normality, its homogeneity and similarity in average for all classes of the population. After all the class known to normal, homogenous and have the same average then conducted the election of class sample randomly. Before testing the hypotheses, firstly applied the normality test and homogenety test to the sample. Then, tested the hypotheses by applying t-test formula. He got that $t_{\text {test }}(1,838)>t_{\text {tabel }}(1,645)$ with 0,05 degree of freedom and with $95 \%$ level of credence. Then he concluded that null hypothesis $\left(H_{0}\right)$ and the alternative hypothesis $\left(H_{1}\right)$ is accepted. So, the ability of the students in understanding Math Concept is higher through the Cooperative Studying Model Lottery Card Type (Arisan's Card) than the students taught through conventional learning.

Keywords: Understanding on mathematic concept's ability, learning model of cooperative (Lottery card).

Peer review under responsibility UIN Imam Bonjol Padang.

(C) 2018 UIN Imam Bonjol Padang. All rights reserved.

p-ISSN: $2580-6726$

e-ISSN: 2598-2133 


\section{PENDAHULUAN}

Proses pembelajaran merupakansuatu proses yang mengandungserangkaian kegiatan pendidik dan peserta didik atasdasarhubungan timbal balik /interaksi yang berlangsung dalam situasi pengajaran untuk mencapai tujuan pembelajaran. Melalui proses pembelajaran diharapkan peserta didik dapat mengembangkan potensi yang telah diberikan oleh Allah SWT. Karena Allah SWT telah menganugerahkan potensi dan kemampuan kepada manusia. Sehingga manusia dituntut untuk untuk belajar dan senantiasa mencari ilmu pengetahuan.

Untuk itu perlu dilakukan pembaharuan dalam bidang pendidikan dari waktu ke waktu tanpa henti. Pemerintah juga telah melakukan usaha-usaha untuk meningkatkan mutu pendidikan di Indonesia. Usaha yang dilakukan pemerintah antara lain: a) Peningkatan kualitas dan kuantitas tenaga kependidikan, b) Pembaharuan kurikulum yang sesuai dengan perkembangan ilmu pengetahuan, teknologi dan tuntutan zaman, c) Serta penyediaan sarana dan prasarana pendidikan yang memadai.

Proses pembelajaran pada saat ini bukan hanya menuntut pendidik untuk hanya berperan sebagai penyampai informasi materi saja tetapi juga bertanggung jawab memajukan, memotivasi dan membimbing peserta didik dalam proses belajarnya. Selain itu pendidik juga diharapkan dapat menjadikan peserta didik terlibat aktif dalam proses pembelajaran. Karena keberhasilan pembelajaran tersebut membutuhkan peranan aktif dari pendidik dan peserta didik.
Matematika merupakan ratu dari ilmu pengetahuan yang lain. Menurut (Suherman dkk, 2003: 25) Matematika sebagai ratunya ilmu dimaksudkan bahwa matematika adalah sebagai sumber dari ilmu yang lain. Karena apapun kegiatan yang dilakukan sehari-hari memerlukan ilmu matematika. Misalnya dalam mengkaji ilmu falaq (perbintangan), dalam hal ini dibutuhkan matematika. Atau contoh lainnya, untuk mengetahui bilangan tahun-tahun, pergantian waktu (siang dan malam), mengetahui masuknya waktu shalat dan lain-lain sebagainya diperlukan perhitungan matematika. Maka tampak jelas bahwa matematika memiliki peranan dalam ilmu pengetahuan.

Berdasarkan Permendiknas No 58 (Depdiknas, 2014) tentang Standar Isi Mata Pelajaran Matematika dinyatakan bahwa pelajaran matematika SMA bertujuan agar para peserta didik SMA: 1) Memahami konsep matematika, merupakan kompetensi dalam menjelaskan keterkaitan antarkonsep dan menggunakan konsep maupun algoritma, secara luwes, akurat, efisien, dan tepat, dalam pemecahan masalah. 2) Menggunakan pola sebagai dugaan dalam penyelesaian masalah, dan mampu membuat generalisasi berdasarkan fenomena atau data yang ada. 3) Menggunakan penalaran pada sifat, melakukan manipulasi matematika baik dalam penyederhanaan, maupun menganalisa komponen yang ada dalam pemecahan masalah dalam konteks matematika maupun di luar matematika (kehidupan nyata, ilmu, dan teknologi) yang meliputi kemampuan memahami masalah, membangun model matematika, menyelesaikan model dan 
Penerapan Model pembelajaran .... (Rivdya Eliza, Riza Setia Eka Putri) 49

menafsirkan solusi yang diperoleh termasuk dalam rangka memecahkan masalah dalam kehidupan sehari-hari (dunia nyata). 4) Mengkomunikasikan gagasan, penalaran serta mampu menyusun bukti matematika dengan menggunakan kalimat lengkap, simbol, tabel, diagram, atau media lain untuk memperjelas keadaan atau masalah. 5) Memiliki sikap menghargai kegunaan matematika dalam kehidupan, yaitu memiliki rasa ingin tahu, perhatian, dan minat dalam mempelajari matematika, serta sikap ulet dan percaya diri dalam pemecahan masalah. 6) Memiliki sikap dan perilaku yang sesuai dengan nilai-nilai dalam matematika dan pembelajarannya, seperti taat azas, konsisten, menjunjung tinggi kesepakatan, toleran, menghargai pendapat orang lain, santun, demokrasi, ulet, tangguh, kreatif, menghargai kesemestaan (konteks, lingkungan), kerjasama, adil, jujur, teliti, cermat, bersikap luwes dan terbuka, memiliki kemauan berbagi rasa dengan orang lain. 7) Melakukan kegiatan-kegiatan motorik yang menggunakan pengetahuan matematika. 8) Menggunakan alat peraga sederhana maupun hasil teknologi untuk melakukan kegiatan-kegiatan matematika.

Mengingat begitu pentingnya peranmatematika maka matematika dijadikan mata pelajaran yang wajib diajarkan di sekolahmulai dari sekolah dasar sampai ke perguruan tinggi. Sebagaimana yang disebutkan dalam UU Sisdiknas No 20 (2003) bahwa peserta didik mengembangkan potensi diri melalui proses pembelajaran yang tersedia pada jalur, jenjang, dan jenis pendidikan tertentu. Oleh karena itu bidang studi matematika diajarkan pada setiap jenjang pendidikan. Selain itu, pada pembelajaran matematika harus terdapat keterkaitan konsep sebelumnya dengan konsep yang akan diajarkan.

Menurut Ruseffendi (1984,

"matematika diajarkan di sekolah karena matematika dapat membantu bidang studi lain, seperti Ilmu Pengetahuan Alam, kedokteran, geografi, ekonomi, bisnis, pendidikan, manajemen, dan psikologi”. Namun mengajarkan matematika tidaklah mudah. Tantangan bagi pendidik adalah memberikan pelajaran matematika dengan baik sehingga tujuanpembelajaran dapat dicapai, oleh karena itu peserta didik harus mempunyai kemampuan pemahaman yangbaik terhadap matematika.

Berdasarkan hasil observasi pembelajaran matematika wajib di MAN Salido yang dilakukan pada tanggal 11Oktober 2016 dapat diketahui bahwa kemampuan pemahamanpeserta didik kelas $\mathrm{X}$ dalam mengikuti pembelajaran masih rendah. Hal ini tampak pada saat pembelajaran berlangsung perhatian peserta didik tidak berpusat pada materi yang diajarkan oleh pendidik. Banyak peserta didik yang enggan untuk bertanya dan kurang terlibat secara aktif dalam proses pembelajaran.

Walaupun begitu proses pembelajaran berlangsungpeserta didik diperintahkan untuk berdiskusi bersama teman sekelompoknya. Namun hal ini tidak berjalan sesuai yang diharapkan. Sebagian besar tugas yang diberikan oleh guru tersebut hanya dikerjakan atau didiskusikan oleh beberapa anggota kelompok, sedangkan yang lainnya tidak ikut berpartisipasi, hanya berpangku tangan dan kurang peduli atau bertanggung jawab dengan kerja kelompoknya. Meskipun ada beberapa anggota kelompok yang 
serius berdiskusi dalam kelompoknya, tetapi sebagian peserta didik tidak ikut berdiskusi dengan kelompoknya dan materi pelajaran tidak tersampaikan dengan baik. Akibatnya tidak semua anggota kelompok memahami dan menguasai tugas yang telah dikerjakan kelompoknya.

Pada saat mengerjakan soal latihan juga terlihat peserta didik masih sering salah dalam menjawab soal-soal yang diberikan. Peserta didik hanya mampu mengerjakan soal-soal yang dicontohkan oleh pendidik. Apabila diberikan soal yang berbeda tetapi hampir sama dengan contoh-contoh sebelumnya, peserta didik terlihat kurang mampu menyelesaikannya. Hal ini menunjukkan bahwa kemampuan pemahaman konsep peserta didik terhadap materi yang diajarkan masih kurang, yang berdampak kepada banyaknya hasil belajar peserta didik yang belum mencapai KKM.Untuk lebih jelasnya, dipaparkan hasil belajar peserta didik pada tabel berikut:

Tabel 1.Persentase Nilai Ujian Tengah Semester II Siswa Kelas X MAN Salido TP. 2016/2017

\begin{tabular}{ccccccc}
\hline \multirow{2}{*}{ No } & \multirow{2}{*}{ Kelas } & \multirow{2}{*}{ JumlahSiswa } & \multicolumn{2}{c}{ Tuntas $(\geq 78)$} & \multicolumn{2}{c}{ TidakTuntas $(<78)$} \\
& & & Jumlah & Persentase & Jumlah & Persentase \\
\hline 1. & X IPA 1 & 26 & 4 & $15 \%$ & 22 & $75 \%$ \\
2. & X IPA 2 & 25 & 7 & $28 \%$ & 18 & $72 \%$ \\
3. & X IPA 3 & 26 & 10 & $38 \%$ & 16 & $62 \%$ \\
4. & X IPS 1 & 21 & 2 & $9 \%$ & 19 & $91 \%$ \\
5. & X IPS 2 & 22 & 8 & $36 \%$ & 14 & $64 \%$ \\
6. & X IPS 3 & 21 & 2 & $9 \%$ & 20 & $91 \%$ \\
7. & X IPK 1 & 27 & 9 & $33 \%$ & 18 & $77 \%$ \\
8. & X IPK 2 & 30 & 9 & $30 \%$ & 21 & $70 \%$ \\
\hline
\end{tabular}

(Sumber: Guru Mata Pelajaran Matematika Kelas X IPA MAN Salido)

Berdasarkan tabel 1.1 dapat dilihat bahwa hasil belajar matematika seluruh peserta didik kelas $\mathrm{X}$ masih banyak yang belum mencapai KKM yang ditetapkan sekolah yaitu 78. Hal ini menunjukkan bahwa hasil belajar peserta didik masih jauh dari yang diharapkan.

Hasil belajar dipengaruhi oleh kemampuan peserta didik dan efektif tidaknya suatu proses pembelajaran. Selain itu penguasaan bahan ajar matematika oleh peserta didik belum sesuai yang diharapkan. Sedangkan Alwi (2001:2) mengatakan bahwa pengajaran matematika sulit diikuti oleh peserta didik. Hal ini menunjukkan bahwa pengajaran matematika sekolah hingga dewasa ini umumnya kurang berhasil.Banyak faktor yang menyebabkan rendahnya prestasi belajar matematika, baik yang berasal dalam dalam diri peserta didik itu sendiri maupun yang berasal dari luar diri peserta didik. Faktor dari dalam diri peserta didik misalnya, motivasi belajar, minat belajar, sikap terhadap matematika, serta kemampuan berfikir konvergen dan divergen.Sedangkan faktor yang berasal dari luar misalnya kemampuan pendidik dalam mengelola proses belajar, sarana belajar, dan lingkungan.Salah satu model pembelajaran yang dapat digunakan adalah model pembelajaran kooperatif.

Model pembelajaran kooperatif merupakan modelpembelajaran yang menekankan adanya kerjasama antar peserta didik dalam kelompoknya untuk tujuan belajar. Dengan menggunakan 
model pembelajaran kooperatif peserta didik dapat berdiskusi dengan temannya dan dibimbing oleh pendidik, sehingga peserta didik memahami materi dan tujuan pembelajaran akan tercapai.

Model pembelajaran kooperatif tipe Lottery Card (Kartu Arisan) adalah salah satu model pembelajaran yang mendorong peserta didik untuk aktif dalam pembelajaran. Dimana peserta didik bekerjasama dalam kelompok untuk mendiskusikan kesesuaian jawaban dari setiap pertanyaan yang keluar dari dalam gelas yang telah dikocok oleh pendidik. Peserta didik dibentuk kelompok dan setiap jawaban digulung dan dimasukkan kedalam gelas kemudian peserta didik yang memegang kartu jawaban menjawab setelah dikocok terlebih dahulu Taufik, dkk (2011: 163). Setiap kelompok mendapatkan kartu jawaban yang sama begitu juga dengan jumlahnya dengan kelompok lain.

\section{METODE}

\section{Jenis Penelitian}

Rancangan penelitian ini menggunakan model Randomized Control Group Only Design. Rancangannya sekelompok subjek yang diambil dari populasi tertentu dikelompokkan secara acak menjadi dua kelompok, yaitu kelompok eksperimen dan kelompok kontrol. Kelompok eksperimen dikenai variabel perlakuan atau treatment, lalu kedua kelompok itu dikenai pengukuran yang sama. Perbedaan yang timbul dianggap bersumber pada variabel perlakuan. Bentuk rancangan penelitian ini dapat dilihat pada tabel 1.2. berikut:
Tabel 2. Rancangan Penelitian

\begin{tabular}{ccc}
\hline Kelas & Perlakuan & Tes akhir \\
\hline Eksperimen & $\mathrm{X}$ & $\mathrm{T}$ \\
Kontrol & - & $\mathrm{T}$ \\
\hline
\end{tabular}

(Sumber: Suryabrata, 2003: 104)

Keterangan:

X: Perlakuan yang diberikan pada kelas eksperimen yaitu Model Pembelajaran Kooperatif Tipe Lottery Card (Kartu Arisan).

T: Tes akhir yang diberikan pada kelas eksperimen dan kelas kontrol.

\section{Waktu dan Tempat Penelitian}

Dalam rancangan ini diambil sekelompok subjek dari populasi kelas X MAN Salido, dikelompokkan menjadi dua kelompok yaitu kelompok eksperimen (X IPA 3) dan kelompok kontrol (X IPA 2).Kelas eksperimen yang sengaja diberi perlakuan (Model Pembelajaran Kooperatif Tipe Lottery Card (Kartu Arisan)) dan kelas kontrol yang tidak menerapkan strategi tersebut. Pada akhir penelitian ini kelas eksperimen dan kelas kontrol diberikan tes untuk melihat hasil belajar matematika kedua kelas tersebut.

\section{Jenis dan Sumber Data}

Data adalah hasil pencatatan penelitian, berupa fakta atau angka. 1) Jenis data adalah data primer yang digunakan dalam penelitian ini adalah data yang langsung diambil dari sampel yang diteliti, dalam hal ini data primer yaitu data kemampuan pemahaman konsep matematis peserta didikyang dapat dilihat dari hasil tes akhir pelajaran matematika pada kelas eksperimen dan kelas kontrol.Data sekunder adalah data yang diperoleh dari orang lain. Dalam hal ini data sekundernya adalah data jumlah peserta didikyang menjadi subjek penelitian dan data nilai Ujian Tengah Semester II kelas X MAN 
Salido. 2) Sumber data adalah sumber data dalam penelitian ini adalah: a) Peserta didikkelas $\mathrm{X}$ MAN Salido tahun pelajaran 2016/2017 untuk mendapatkan data primer. b) Pendidik bidang studi matematika MAN Salido tahun pelajaran 2016/2017 dan Tata Usaha untuk mendapatkan data sekunder.

\section{Teknik Analisis Data}

Analisis data bertujuan untuk menguji hipotesis yang diajukan apakah diterima atau ditolak.Data berasal dari instrumen penelitian yaitu tes akhir yang mengandung indikator kemampuan pemahaman konsep yang dilakukan pada pertemuan terakhir penelitian.Selanjutnya melakukan uji statistik yang digunakan untuk menguji hipotesis. Sebelum melakukan uji hipotesis terlebih dahulu dilakukan uji normalitas dan uji homogenitas terhadap kelas sampel. Dalam menganalisis data, dilakukan langkahlangkah sebagai berikut:1)Menghitung Skor Kemampuan Pemahaman Konsep Matematis Siswa. Analisis ini digunakan untuk memperoleh informasi tentang kemampuan pemahaman konsep matematis peserta didik. Kemampuan pemahaman konsep matematis siswa dinilai dari tes akhir yang mengandung indikator kemampuan pemahaman konsepdengan penerapan Model Pembelajaran Kooperatif TipeLottery Card (Kartu Arisan). 2)Uji Normalitas bertujuan untuk melihat apakah kedua kelas sampel berdistribusi normal atau tidak. Untuk melakukan uji normalitas ini dibantu dengan menggunakan software SPSS.3) Uji Homogenitasbertujuan untuk menyelidiki apakah kedua kelompok sampel mempunyai variansi yang homogen atau tidak. Rumus yang digunakan untuk mengujinya menurut Sudjana (2005: 249) adalah:

$$
F=\frac{S_{1}{ }^{2}}{S_{2}{ }^{2}}
$$

Keterangan:

$\mathrm{S}_{1}^{2}=$ variansi hasil belajar kelas eksperimen

$\mathrm{S}_{2}^{2}=$ variansi hasil belajar kelas kontrol

Hipotesis yang diajukan:

$H_{0}$ :sampel mempunyai varians yang sama

$H_{1}$ : sampel mempunyai varians yang tidak sama

Kriteria pengujian:

Terima $H_{0}$ jika $F_{\text {hitung }}<F_{\text {tabel }}$

Uji HipotesisSetelah dilakukan uji normalitas dan uji homogenitas pada kedua kelompok sampel maka dapat dilakukan uji hipotesis. Uji hipotesis bertujuan untuk mengetahui apakah hipotesis penelitian diterima atau ditolak. Berdasarkan hipotesis yang dikemukan maka dilakukan uji satu pihak. Hipotesis yang diuji adalah :

Dimana :

$$
\begin{aligned}
& \mathrm{H}_{0}: \mu_{1}=\mu_{2} \\
& \mathrm{H}_{1}: \mu_{1}>\mu_{2}
\end{aligned}
$$

$$
\begin{aligned}
& \mu_{1} \quad \text { :Rata-rata kemampuan pemahaman } \\
& \text { konsep peserta didikkelas eksperimen } \\
& \mu_{2} \quad: \text { Rata-rata kemampuan pemahaman } \\
& \text { konsep peserta didikkelas control }
\end{aligned}
$$

Apabila data distribusi normal dan mempunyai variansi homogen maka uji statistik yang digunakan menurut Sudjana (2005: 239) adalah: 


$$
t=\frac{\overline{X_{1}}-\overline{X_{2}}}{S \sqrt{\frac{1}{n_{1}}+\frac{1}{n_{2}}}}
$$

Dengan

$$
S=\sqrt{\frac{\left(n_{1}-1\right) S_{1}^{2}+\left(n_{2}-1\right) S_{2}^{2}}{n_{1}+n_{2}-2}}
$$

Dimana:

$\overline{x_{1}}=$ Nilai rata-rata kelompok eksperimen

$\overline{x_{2}}=$ Nilai rata-rata kelompok kontrol

$S_{1}^{2}=$ Variansi kelas eksperimen

$S_{2}{ }^{2}=$ Variansi kelas kontrol

$n_{1}=$ Banyak siswa kelas eksperimen

$n_{2}=$ Banyak siswa kelas kontrol

Kriteria pengujian $H_{0}$ diterima jika $t_{\text {hitung }}<$ $\mathrm{t}_{\text {tabel }}$ dapat dilihat pada daftar distribusi $\mathrm{t}$ dengan derajat kebebasan df $=\mathrm{n}_{1}+\mathrm{n}_{2}-2$ dan peluang $(1-\alpha)$. Hipotesis nol ditola $\mathrm{k}$ jika $\mathrm{t}_{\text {hitung }} \geq_{\mathrm{t}_{\text {tabel }}}$ yang dapat dilihat pada daftar distribusi t dengan derajat kebebasan df $=\mathrm{n}_{1}+\mathrm{n}_{2}-2$ pada taraf signifikan 0,05 .

\section{HASIL PENELITIAN DAN PEMBAHASAN}

Data hasil kemampuan pemahaman konsep matematispeserta didikpada kelas sampel diperoleh setelah diberikan tes akhir pada pokok bahasan Fungsi.Kesimpulan hasil perhitungan tersebut dapat dilihat pada tabel sebagai berikut:

Tabel 3. Data Hasil Perhitungan Tes Kemamapuan Pemahaman Konsep

\begin{tabular}{cccc}
\hline No & Interval Nilai & Eksperimen & Kontrol \\
\hline 1 & $21-30$ & - & - \\
2 & $31-40$ & 1 & 2 \\
3 & $41-50$ & - & - \\
4 & $51-60$ & 2 & 3 \\
5 & $61-70$ & 4 & 5 \\
6 & $71-80$ & 8 & 8 \\
7 & $81-90$ & 8 & 7 \\
8 & $91-100$ & 3 & - \\
\hline \multicolumn{5}{c}{ Nilai Max } & 26 & 25 \\
& Nilai Min & 45 & 90 \\
& & Tuntas $(53.84 \%)$ & 33 \\
PersentaseKetuntasan & Tidak Tuntas $(46.16 \%)$ & Tidak Tuntas $(57.7 \%)$ \\
& $\bar{X}$ & 76.692 & 71.480 \\
& $S^{2}$ & 166.141 & 209.76 \\
S & 12.8895 & 14.483 \\
\hline
\end{tabular}

Dari tabel di atas dapat dilihat bahwa ratarata nilai matematika pada kelas eksperimen adalah 76.692, lebih tinggi dari rata-rata pada kelas kontrol yaitu 71.480. Nilai maksimum hasil tes yang diperoleh oleh kelas eksperimen adalah 95 lebih tinggi dari kelas kontrol yaitu 90, sedangkan nilai minimum yang diperoleh oleh kelas eksperimen adalah 40 dan kelas kontrol adalah 33 .
Berdasarkan Kriteria Ketuntasan Minimal (KKM) yang ditetapkan di MAN Salido yaitu 78, dari hasil tes pemahaman konsep matematis peserta didikpada kelas eksperimen diketahui bahwa nilai peserta didikyang mencapai KKM sebanyak 14 orang, sedangkan pada kelas kontrol sebanyak 10 orang, sehingga persentase ketuntasan belajar matematika peserta didikkelas eksperimen adalah $53.84 \%$ dan pada kelas kontrol adalah $40 \%$. Sehingga dapat terlihat bahwa 
kemampuan pemahaman konsep matematis peserta didikkelas eksperimen lebih tinggi dibandingkan kemampuan pemahaman konsep matematis peserta didikkelas kontrol.

Data tentang kemampuan pemahaman konsep matematis peserta didikdiperoleh melalui tes akhir yaitu tes kemampuanpemahaman konsep matematis. Soal tes kemampuan pemahaman konsep terdiri dari 5 butir soal essay yang memuat lima indikator kemampuan pemahaman konsep, yaitu: 1) Menentukan objek menurut notasi relasi dan fungsi tertentu. 2) Mengklasifikasikan objek menurut jenis - jenis tertentu sesuai dengan konsepnya 3)

Tabel 4. Nilai Rata-rata Siswa Setiap Indikator KemampuanPemahaman Konsep pada Kelas Sampel

\begin{tabular}{lcc}
\hline \multicolumn{1}{c}{ Indikator Kemampuan Pemahaman Konsep } & \multicolumn{2}{c}{ Nilai Rata-rata } \\
Eksperimen & Kontrol \\
\hline Menentukan objek menurut notasi relasi dan fungsi tertentu. & 88.46 & 89.78 \\
Mengklasifikasikan objek menurut jenis - jenis tertentu sesuai & 96.34 & 88.20 \\
dengan konsepnya & & \\
Mengklasifikasikan objek menurut Sifat - sifat tertentu sesuai & 88.94 & 86.35 \\
dengan konsepnya & 70.19 & 68.19 \\
Menyajikan kosep dalam bentuk operasi matematis & 65.53 & 50.76 \\
\hline
\end{tabular}

Selain itu nilai rata-rata setiap indikator kemampuan pemahaman konsep pada kelas sampel dapat juga dilihat pada diagram berikut:

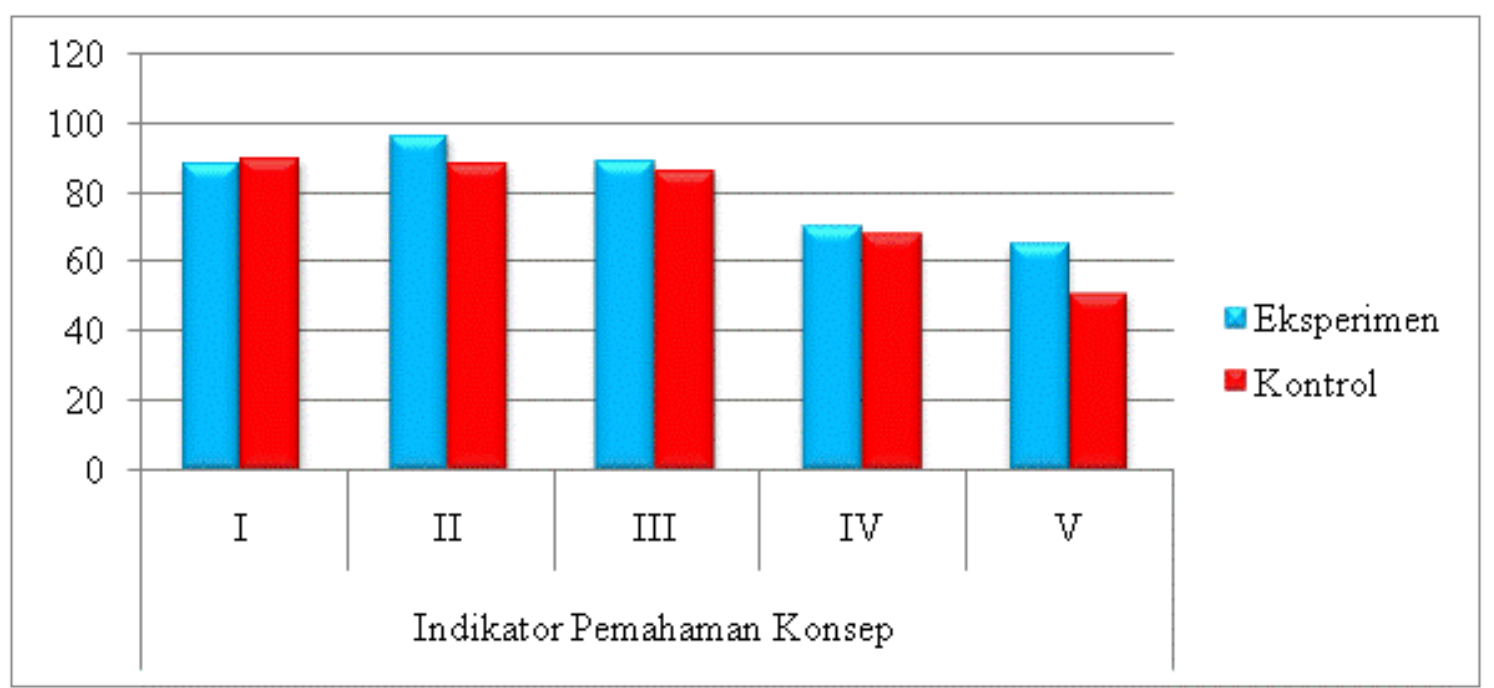

Gambar 1: Nilai rata-rata setiap indikator kemampuan pemahaman konsep pada kelas sampel Keterangan Indikator:

I. Menentukan objek menurut notasi relasi dan fungsi tertentu.

II. Mengklasifikasikan objek menurut jenis - jenis tertentu sesuai dengan konsepnya 
III. Mengklasifikasikan objek menurut Sifat - sifat tertentu sesuai dengan konsepnya

IV. Menyajikan kosep dalam bentuk operasi matematis.

V. Menyajikan konsep dalam bentuk operasi komposisi matematis.

Gambar 1. menjelaskan bahwa nilai rata rata setiap indikator kemampuan pemahaman konsep matematis peserta didik tidak jauh berbeda. Pada indikator I yaitu Menentukan objek menurut notasi relasi dan fungsi tertentu diperoleh nilai kelas eksperimen 88.46 dan kelas kontrol 89,78. Indikator II Mengklasifikasikan objek menurut jenis - jenis tertentu sesuai dengan konsep diperoleh nilai 96.34 pada kelas eksperimen dan 88.20 pada kelas kontrol. Nilai indikator III yaitu Mengklasifikasikan objek menurut Sifat - sifat tertentu sesuai dengan konsep kelas eksperimen adalah 88.94 dan 86.35 pada kelas kontrol. Indikator IV yaitu Menyajikan kosep dalam bentuk operasi matematis diperoleh nilai kelas eksperimen adalah 70.19 dan 68.19 pada kelas kontrol. Sedangkan indikator V yaitu Menyajikan konsep dalam bentuk operasi komposisi matematis diperoleh nilai pada kelas eksperimen adalah 65.53dan 50.76 pada kelas kontrol.

Berdasarkan analisis di atas dapat diketahui bahwa pada umumnya nilai rata-rata peserta didik setiap indikator kemampuan pemahaman konsep di kelas eksperimen lebih tinggi dibandingkan kelas kontrol. Maka dapat disimpulkan bahwa kemampuan pemahaman konsep matematis pada kelas eksperimen lebih tinggoli dibandingkan kelas kontrol. Hal ini berarti kemampuan pemahaman konsep matematis peserta didik yang diajarkan dengan Model Pembelajaran Kooperatif Tipe Lottery Card (Kartu Arisan) lebih baik dibandingkan peserta didik yang diajarkan dengan model pembelajaran konvensional.

Untuk memperoleh kesimpulan tentang data hasil kemampuan pemahaman konsep matematis peserta didikdilakukan analisis secara statistik. Sebelum uji statistik untuk hipotesis, terlebih dahulu dilakukan uji normalitas dan uji homogenitas. 1) Uji Normalitasbertujuan untuk melihat apakah kedua kelompok data berdistribusi normal atau tidak. Untuk uji normalitas ini menggunakan uji Liliefors. Berdasarkan hasil uji Liliefors yang dilakukan, maka didapatkan kesimpulan sebagaimana yang terdapat pada tabel di bawah ini:

Tabel 5. Tabel perbandingan $L_{0}$ dan $L_{t a b e l}$

\begin{tabular}{cccccc}
\hline No. & Kelas & $\mathbf{L}_{\mathbf{0}}$ & $\mathbf{L}_{\text {Tabel }}$ & Kesimpulan & Keterangan \\
\hline 1 & Eksperimen & 0,0778 & 0,1737 & $\mathrm{~L}_{0}<\mathrm{L}_{\text {Tabel }}$ & Data Normal \\
2 & Kontrol & 0,1092 & 0,1772 & $\mathrm{~L}_{0}<\mathrm{L}_{\text {Tabel }}$ & Data Normal \\
\hline
\end{tabular}

Selain itu untuk menentukan data berdistribusi normal atau tidak, penulis juga melakukan pengujian normalitas dengan sofware
SPSS. Dengan menggunakan bantuan software SPSS dapat dilihat hasil uji normalitas kedua kelas sampel sebagai berikut:

\section{Tabel 6. Tests of Normality Sampel}

\begin{tabular}{lccccccc}
\hline & & \multicolumn{8}{c}{ Tests of Normality } \\
& \multirow{2}{*}{ Kelas } & Kolmogorov-Smirnov & \multicolumn{3}{c}{ Shapiro-Wilk } \\
& X tatistic & Df & Sig. & Statistic & Df & Sig. \\
\hline \multirow{2}{*}{ Nilai } & X IPA 3 & $\mathbf{1 1 0}$ & $\mathbf{2 6}$ & $\mathbf{2 0 0}$ & $\mathbf{9 2 6}$ & $\mathbf{2 6}$ & $\mathbf{1 6 9}$ \\
& X IPA 2 & $\mathbf{, 1 0 0}$ & $\mathbf{2 5}$ & $\mathbf{2 0 0}$ & $\mathbf{9 3 6}$ & $\mathbf{3 0}$ & $\mathbf{0 5 6}$ \\
\hline
\end{tabular}


Dari tabel di atas dapat dilihat bahwa signifikan kelas eksperimen dan kontrol lebih besar dari 0,05. Pada uji Kolmogorov Smirnov nilai signifikan masing-masing kelas adalah0.200 dan 0.200, dan pada uji Shapiro Wilk adalah 0,169 dan 0,056 yang keduanya lebih besar dari 0,05, sehingga dapat disimpulkan bahwa kedua kelas sampel berdistribusi normal. 1) Uji homogenitas variansi dilakukan untuk melihat apakah kedua kelompok data mempunyai variansi yang homogen atau tidak. Pengujian ini dilakukan dengan menggunakan uji F.Pasangan hipotesis yang akan diuji adalah:

$$
\begin{aligned}
& \mathrm{H}_{0}: \sigma_{1}^{2}=\sigma_{2}^{2} \\
& \mathrm{H}_{1}: \sigma_{1}^{2} \neq \sigma_{2}^{2}
\end{aligned}
$$

Kriteria pengujiannya adalah;

a. Terima $H_{0}$ jika $F_{\text {hitung }}<F_{\left(\alpha ; v_{1}, v_{2}\right)}$

b. Tolak $H_{0}$ jika $F_{\text {hitung }} \geq F_{\left(\alpha ; v_{1}, v_{2}\right)}$

Berdasarkan tabel distribusi $\mathrm{F}$ didapatkan nilai $F_{\text {tabel }}$ untuk taraf nyata $\alpha=0,05$ dan derajat kebebasan $(d f)=\left(\mathrm{n}_{1}-1, \mathrm{n}_{2}-1\right)=(26,25)$ adalah 1.705 . Maka diperoleh $F_{\text {hitung }}<F_{\left(\alpha ; v_{1}, v_{2}\right)}(0.792<1,705)$ sehingga dapat disimpulkan bahwa kedua kelas sampel memiliki variansi yang homogen. 2) Uji Hipotesisdilakukan untuk menentukan apakah kemampuan pemahaman konsep matematis peserta didikkelas eksperimen lebih meningkat dari pada kelas kontrol dengan menggunakan ujit. Dengan $\alpha=0,05$ dan $d k=\mathrm{n}_{1}+\mathrm{n}_{2}-2=26+25-$ $2=49$, maka diperoleh $t_{\text {hitung }}=1.838$, sedangkan $\mathrm{t}_{\text {tabel }}$ dengan taraf kepercayaan $95 \%$ adalah $\mathrm{t}_{\text {tabel }}=$ 1,645. Karena $t_{\text {hitung }}>t_{\text {tabel }}$ maka hipotesis $H_{0}$ ditolak dan $\mathrm{H}_{1}$ diterima.
Jadi, kemampuan pemahaman konsep matematis peserta didikyang diajarkan dengan Model Pembelajaran Kooperatif TipeLottery Card (Kartu Arisan) lebih tinggi dari kemampuan pemahaman konsep matematis peserta didikyang diajarkan dengan model pembelajaran konvensional.

Berdasarkan hasil deskripsi dan analisis data diperoleh bahwa nilai rata-rata kelas eksperimen lebih tinggi dari kelas kontrol. Perbedaan ini disebabkan karena perlakuan yang diberikan berbeda. Pada kelas eksperimen diberikan model pembelajaran kooperatif. Pembelajaran kooperatif merupakan pembelajaran yang tidak terfokus hanya pada pendidik dan buku ajar tetapi adanya kerja sama antar siswa (Wena, 2009: 189), hingga tidak ada lagi sebuah kelas yang sunyi selama proses pembelajaran, karena pendidik dan peserta didiksama-sama berusaha untuk mencapai ketuntasan dalam proses belajar-mengajar.

Pada kelas eksperimen kegiatan yang diterapkan adalah Model Pembelajaran Kooperatif Tipe Lottery Card (Kartu Arisan). Pembelajaran ini menempatkan peserta didik ke dalam kelompok-kelompok kecil yang heterogen, kemudian peserta didikbekerja sama dalam kelompok untuk mendiskusikan kesesuaian jawaban dari setiap pertanyaan yang keluar dari dalam gelas yang dikocok oleh pendidik. Pembagian kelompok yang heterogen menjadikan siswa saling membantu satu sama lain. Siswa yang memiliki kemampuan tinggi dapat membantu peserta didikyang kemampuannya lebih rendah dalam penyelesaian soal-soal. Sebagaimana dalam interaksi promotif terdapat 
salah satu ciri-cirinya yaitu saling membantu secara efektif dan efisien (Suprijono, 2014: 60).

$$
\text { Pada pertemuan pertama dikelas }
$$
eksperimen, ada beberapa orang diantara peserta didikyang kurang setuju dengan anggota kelompok yang sudah ditetapkan. Peserta didiktersebut beralasan ingin sekelompok dengan teman dekatnya. Namun setelah diberikan penjelasan tentang bagaimana cara pembagian kelompok tersebut kepada peserta didik, akhirnya peserta didik yang awalnya menolak mau menerima keputusan yang telah ditetapkan oleh pendidik.

Pada awal pembelajaran pendidik menayangkan slide dengan menggunakan infocus di depan kelas, yaitu mengenai materi yang akan diajarkan. Kemudian pendidik membagikan LKS dan kartu jawaban kepada masing-masing peserta didik. Sementara itu kartu soal dimasukkan ke dalam gelas tempat soal. Setelah gelas soal dikocok, pendidik membacakan soal yang keluar dari gelas dan peserta didikberdiskusi dengan anggota kelompoknya untuk mencari kesesuaian jawaban dari soal yang muncul.

Kelompok yang memiliki kartu jawaban yang sesuai dengan soal dipersilakan untuk mengacungkan tangan dan perwakilan dari kelompok tersebut mempresentasikan jawabannya. Jika jawabannya benar maka kelompok tersebut mendapat point 1 dan kelompok lain memberikan applause. Namun jika jawabannya salah maka kelompok penyaji mendapat point 0 . Setelah selesai melaksanakan Model Pembelajaran Kooperatif Tipe Lottery Card (Kartu Arisan) selanjutnya peserta didikmelaksanakan kuis untuk menguji kemampuan pemahaman konsep matematis peserta didiktentang materi yang telah diajarkan dengan rata - rata nilai adalah 65 , dimana peserta didikyang tuntas sebanyak 9 orang dari 26 peserta didik.

Pada pertemuan kedua sampai kelima dikelas eksperimen, dengan cara yang sama pendidik membagikan LKS dan kartu jawaban kepada masing-masing peserta didik. Setelah selesai melaksanakan Model Pembelajaran Kooperatif Tipe Lottery Card (Kartu Arisan) selanjutnya peserta didikmelaksanakan kuis untuk menguji kemampuan pemahaman konsep matematis peserta didiktentang materi yang telah diajarkan. Hasil dari nilai tiap - tiap pertemuan sebagai berikut; pertemuan kedua dengan rata rata nilai adalah 60, dimana peserta didikyang tuntas sebanyak 7 orang dari 26 peserta didik, pertemuan ketiga dengan rata - rata nilai adalah 68, dimana peserta didikyang tuntas sebanyak 6 orang dari 26 peserta didik, pertemuan keempat dengan rata - rata nilai adalah 70 , dimana peserta didikyang tuntas sebanyak 12 orang dari 26 peserta didik, pertemuan kelima dengan rata rata nilai adalah 75 , dimana peserta didikyang tuntas sebanyak 10 orang dari 26 peserta didik.

Ketika melaksanakan penelitian, terlihat bahwa pembelajaran dengan kartu arisan ini mampu membuat peserta didikmenjadi aktif. Soal-soal yang diberikan membuat peserta didik berantusias untuk menyelesaikannya. Karena peserta didikmenginginkan kelompoknya memperoleh point tertinggi nantinya. Oleh karena itu masing-masing kelompok berusaha semaksimal mungkin untuk mencari jawaban dari setiap soal yang muncul. Hal ini sesuai dengan pernyataan Sanjaya (2008: 246) bahwa dalam pembelajaran kelompok, keberhasilan 
suatu penyelesaian tugas sangat tergantung kepada usaha yang dilakukan setiap anggota kelompoknya.

Pada kemampuan pemahaman konsep matematis terlihat naik dan turunnya nilai kuis siswa yang kurang memperhatikan sewaktu presentasi kelompok, dan ada juga yang tidak aktif dalam mengikuti diskusi kelompok. peserta didikyang demikian diberikan peringatan oleh pendidik agar memperhatikan dan mengikuti diskusi kelompoknya. Peringatan yang diberikan ini merupakan pemprosesan kelompok. Suprijono (2014: 61) menyatakan bahwa pemprosesan mengandung arti menilai. Tujuan pemprosesan kelompok adalah meningkatkan efektivitas anggota dalam memberikan kontribusi terhadap kegiatan kolaboratif untuk mencapai tujuan kelompok. Setelah diberikan peringatan oleh pendidik, pada pertemuan berikutnya pada umumnya peserta didikmau berdiskusi dengan kelompoknya masing-masing.

Pada pertemuan pertama kelas kontrol menggunakan pembelajaran secara konvensional, saat pendidik menerangkan pelajaran hanya sebagian peserta didikyang memperhatikan terutama pada barisan depan. Sewaktu diberikan LKS, beberapa peserta didiktidak mengerjakan dengan alasan tidak mengerti. Hal yang menyebabkan rendahnya pemahaman konsep peserta didikpada kelas kontrol ini adalah kurangnya keaktifan peserta didikmengikuti pembelajaran dan apabila mereka mendapat kendala dalam menyelesaikan soal mereka tidak berusaha menyelesaikan soal tersebut dan juga kurang mau bertanya kepada teman ataupun pendidik. Setelah menyelesaikan LKS yang diberikan pendidik, peserta didikdiberikan kuis untuk menuji kemampuan pemahaman konsep matematis peserta didiktentang materi yang telah diajarkan dengan rata - rata nilai adalah 55, dimana peserta didikyang tuntas sebanyak 5 orang dari 25 peserta didik.

Pada pertemuan kedua sampai kelima dikelas kontrol, dengan cara yang sama pendidik membagikan LKS kepada masing-masing peserta didik. Setelah pendidik selesai melaksanakan pembelajaran secara konvensional, selanjutnya peserta didikmelaksanakan kuis untuk menguji kemampuan pemahaman konsep matematis siswa tentang materi yang telah diajarkan. Hasil dari nilai tiap - tiap pertemuan sebagai berikut; pertemuan kedua dengan rata - rata nilai adalah 60 , dimana peserta didik yang tuntas sebanyak 8 orang dari 25 peserta didik, pertemuan ketiga dengan rata - rata nilai adalah 50, dimana peserta didik yang tuntas sebanyak 5 orang dari 25 peserta didik, pertemuan keempat dengan rata rata nilai adalah 65 , dimana peserta didik yang tuntas sebanyak 8 orang dari 25 peserta didik, pertemuan kelima dengan rata - rata nilai adalah 70 , dimana peserta didik yang tuntas sebanyak 10 orang dari 25 peserta didik.

Apabila ditinjau dari tes akhir, diperoleh bahwa hasil tes kemampuan pemahaman konsep matematis peserta didikkelas eksperimen dengan menerapkan Model Pembelajaran Kooperatif Tipe Lottery Card (Kartu Arisan) lebih tinggi dari pada kemampuan pemahaman konsep matematis peserta didikyang menerapkan pembelajaran konvensional.Hal ini terlihat dari nilai rata-rata kelas eksperimen lebih tinggi daripada kelas kontrol. Rata-rata pada kelas 
Penerapan Model pembelajaran .... (Rivdya Eliza, Riza Setia Eka Putri) 59

eksperimen adalah 76.692 sedangkan kelas kontrol 71.480 dan nilai tertinggi kelas eksperimen adalah 95 sedangkan pada kelas kontrol 90, serta nilai terendah kelas eksperimen adalah 40 dan nilai terendah pada kelas kontrol adalah 33 .

Pada kelas eksperimen jumlah peserta didikyang mencapai nilai lebih dari atau sama dengan nilai KKM yang ditetapkan oleh MAN Salido yaitu 78, sebanyak 14peserta didikdengan persentase ketuntasan $53.84 \%$. Sedangkan pada kelas kontrol sebanyak 10peserta didik dengan persentase ketuntasan $42.30 \%$. Sehingga dapat terlihat bahwa kemampuan pemahaman konsep matematis peserta didik kelas eksperimen lebih tinggi dari kemampuanpemahaman konsep matematis peserta didik kelas kontrol.

Hasil penelitian yang dilakukan di kelas XIPA 3 MAN Salido, terlihat bahwa penerapan Model Pembelajaran Kooperatif Tipe Lottery Card (Kartu Arisan)mampu meningkatkan kemampuan pemahaman konsep matematispeserta didikselama proses pembelajaran berlangsung. Dari hasil penilaian pada aspek kognitif, terlihat bahwa kemampuan pemahaman konsep matematispeserta didikpada kelas eksperimen ada peningkatan.

Maka dapat disimpulkan bahwa kemampuan pemahaman konsep matematis pada kelas eksperimen lebih tinggi dibandingkan kelas kontrol. Hal ini berarti kemampuan pemahaman konsep matematis peserta didikyang diajarkan dengan Model Pembelajaran Kooperatif Tipe Lottery Card (Kartu Arisan) lebih baik dibandingkan peserta didikyang diajarkan dengan model pembelajaran konvensional.

\section{SIMPULAN DAN SARAN}

\section{Simpulan}

Berdasarkan penelitian yang telah dilakukan dapat diambil kesimpulan bahwa kemampuan pemahaman konsep matematis peserta didikyang diajarkan dengan Model Pembelajaran Kooperatif Tipe Lottery Card (Kartu Arisan)lebih tinggi dari kemampuan pemahaman konsep matematis peserta didik yang diajarkan dengan model pembelajaran konvensionalpada peserta didikkelas X MAN Salidodalam taraf nyata alfa 0,05.Rata-rata hasil tes akhir peserta didik pada kelas eksperimen lebih tinggi dibandingkan dengan rata-rata tes akhir peserta didikpada kelas kontrol. Rata-rata tes akhir peserta didikpada kelas eksperimen adalah 76.69 dan pada kelas kontrol 71.48. Jika dilihat dari ketuntasan hasil tes akhir peserta didik, pada kelas eksperimen terdapat 14peserta didikatau sebanyak $53.84 \%$ peserta didikyang memenuhi Kriteria Ketuntasan Minimun (KKM) dari 26 peserta didik yang ada. Sedangkan pada kelas kontrol terdapat 10peserta didik atau sebesar $42.30 \%$ peserta didik yang nilainya mencapai KKM dari 25 peserta didikyang ada.Hal ini juga dapat dilihat dari uji hipotesis diperoleh $t_{\text {tabel }}=1,645$ dan $t_{\text {hitung }}=1.838$ sehingga didapatkan $t_{\text {hitung }}>t_{\text {tabel }} \quad(1.838>1,645)$ pada selang kepercayaan $95 \%$. Karena $t_{\text {hitung }}>t_{\text {tabel }}$ maka hipotesis dalam penelitian ini diterima, artinya kemampuan pemahaman konsep matematis peserta didikyang diajarkan dengan Model Pembelajaran Kooperatif Tipe Lottery Card (Kartu Arisan) lebih tinggi dari kemampuan pemahaman konsep matematis peserta didik yang diajarkan dengan model pembelajaran konvensional. 


\section{Saran}

Berdasarkan kesimpulan yang diperoleh dari penelitian ini maka disarankan sebagai berikut : 1) Diharapkan pada pendidik bidang studi matematika untuk dapat menerapkan Model Pembelajaran Kooperatif Tipe Lottery Card (Kartu Arisan) sebagai salah satu alternatif untuk meningkatkan kemampuan pemahaman konsep matematis peserta didik pada pokok bahasan fungsi. 2). Kepada pembaca diharapkan agar hasil penelitian ini dijadikan sebagai salah satu wadah untuk memperkaya wawasan yang telah dimiliki.

\section{DAFTAR PUSTAKA}

Alwi, Hasan et. al. 2002 Kamus Besar Bahasa Indonesia Jakarta: Balai Pustaka.

Anurrahman. 2010. Belajar dan Pembelajaran. Bandung: Penerbit Alfabeta

Arikunto, Suharsimi.2010. Prosedur Penelitian Suatu Pendekatan Praktik. Jakarta:Rineka Cipta.

.2007. Dasar-Dasar Evaluasi Pendidikan. Jakarta: Bumi Aksara

Hamalik, Oemar. Pembinaan dan Pengembangan Kurikulum, Bandung: Pustaka Martiana, 1981.

Iryanti, Puji. (2004). Peniliaian Unjuk Kerja. Yogyakarta: Depdiknas

Kemendikbud Nomor 104 Tahun 2014 tentang Penilaian Hasil Belajar Oleh Pendidik pada Pendidikan Dasar dan Pendidikan Menengah

Lie, Anita. 2010. Cooperative Learning, Jakarta: Gramedia

Nasution. 2010. Berbagai Pendekatan Dalam Proses Belajar dan Mengajar. Bandung:Bumi Aksara

Prawironegoro, Pratiknyo. 1985. Evaluasi Hasil Belajar Matematika Siswa Khusus
Analisis Soal Untuk Bidang Studi Matematika. Jakarta: P2LLPTK

Rahman, Afzalur. 1992. Al-Qur'an Sumber Ilmu Pengetahuan. Jakarta: Rineka Cipta

Ruseffendi. E.T. 1984. Dasar-Dasar Matematika Kontemporer Untuk Guru. Bandung: Tarsito

Sanjaya, Wina. 2008. Kurikulum dan Pembelajaran. Jakarta : Rineka Cipta

Slameto. 2002. Belajardan Faktor-Faktor yang Mempengaruhi. Jakarta: Rineka Cipta

Sudjana. 2005. Metode Statistik. Bandung: Transito

Sudjana, Nana. 2000. Dasar-dasar Proses Belajar Mengajar. Sinar Baru Algensindo. Bandung.

Suherman, Erman, dkk. 2003. Strategi Belajar Mengajar Matematika. Jakarta: Depdikbud

Suprijono, Agus. 2014. Cooperatif Learning. Yogyakarta: Pustaka Pelajar

Suryabrata, Sumadi. 2003. Metodologi Penelitian. Jakarta: Raja Grafindo Persada

Susanto, Ahmad. 2013. Teori Belajar dan Pembelajaran di Sekolah Dasar. Jakarta: Kencana Prenada Media Group

Taufik, dkk. 2011. Mozaik Pembelajaran Inovatif. Padang: Sukabina Press

Trianto. 2010. Mendesain Model Pembelajaran Inovatif Progregsiv.Jakarta: Prenada Media Group

Undang-Undang Sisdiknas 2003. 2007. Jakarta: Sinar Grafika

Uno, Hamzah dan Moh, Nurdin. 2011. Belajar Dengan Pendekatan PAILKEM, Jakarta: Bumi Aksara

Wena, Made. 2009. Strategi Pembelajaran Inovatif Kontemporer Suatu Tinjauan Konseptual Operasional. Jakarta: Bumi Aksara. 